\title{
Synthetic algal-bacteria consortia for space-efficient microalgal growth in a simple hydrogel system
}

\author{
Noah Martin ${ }^{1}$. Tatum Bernat ${ }^{1}$. Julie Dinasquet ${ }^{1}$. Andrea Stofko ${ }^{1}$. April Damon ${ }^{1}$. Dimitri D. Deheyn ${ }^{1}$. \\ Farooq Azam ${ }^{1}$. Jennifer E. Smith ${ }^{1}$ - Matthew P. Davey ${ }^{2,3}$. Alison G. Smith ${ }^{2}$. Silvia Vignolini ${ }^{4}$. \\ Daniel Wangpraseurt ${ }^{1,4,5}$ (D)
}

Received: 2 March 2021 / Revised and accepted: 9 June 2021 / Published online: 15 July 2021

(c) The Author(s) 2021

\begin{abstract}
Photosynthetic microalgae are an attractive source of food, fuel, or nutraceuticals, but commercial production of microalgae is limited by low spatial efficiency. In the present study we developed a simple photosynthetic hydrogel system that cultivates the green microalga, Marinichlorella kaistiae KAS603, together with a novel strain of the bacteria, Erythrobacter sp. We tested the performance of the co-culture in the hydrogel using a combination of chlorophyll- $a$ fluorimetry, microsensing, and bio-optical measurements. Our results showed that growth rates in algal-bacterial hydrogels were about threefold enhanced compared to hydrogels with algae alone. Chlorophyll- $a$ fluorimetry-based light curves found that electron transport rates were enhanced about $20 \%$ for algal-bacterial hydrogels compared to algal hydrogels for intermediate irradiance levels. We also show that the living hydrogel is stable under different environmental conditions and when exposed to natural seawater. Our study provides a potential bio-inspired solution for problems that limit the space-efficient cultivation of microalgae for biotechnological applications.
\end{abstract}

Keywords Co-culture $\cdot$ Algae-bacteria $\cdot$ Hydrogel $\cdot$ Photosynthesis $\cdot$ Biopolymer $\cdot$ Erythrobacter $\cdot$ Marinichlorella . Synthetic consortia

\section{Introduction}

Microscopic photosynthesizing algae produce a range of high value products including lipids and pigments (Borowitzka 2013). In addition, algal biomass is of great

Noah Martin and Tatum Bernat are shared first author.

Daniel Wangpraseurt

dwangpraseurt@eng.ucsd.edu

1 Marine Biology Research Division, Scripps Institution of Oceanography, University of California San Diego, La Jolla, CA 92093-0205, USA

2 Department of Plant Sciences, University of Cambridge, Cambridge CB2 3EA, UK

3 Scottish Association for Marine Science, Oban PA37 1QA, UK

4 Department of Chemistry, University of Cambridge, Cambridge CB2 1TN, UK

5 Department of Nanoengineering, University of California San Diego, La Jolla, CA 92093-0205, USA interest for use as feedstocks in aquaculture and for the generation of biofuels (Villarruel-Lopez et al. 2017; Khan et al. 2018). However, commercial large-scale production of microalgae is still limited by low spatial efficiency and associated high production and processing costs (e.g., Borowitzka and Vonshak 2017). Algal cultivation techniques can generally be divided into open pond systems, closed photobioreactors, and biofilm-based systems (Posten 2009). Open pond systems cultivate algae in raceway ponds and have low maintenance cost but generate only limited biomass per area (Tan et al. 2020). Photobioreactor systems allow for controlled conditions of irradiance, gas flux and temperature, and yield higher algal growth efficiencies, but have high operation and maintenance costs (Lee 2001; Tan et al. 2020). Biofilm-based systems cultivate algae as surface-attached biofilms rather than in liquid suspensions. Algal biofilm cultivation can lead to reduced operation costs due to limited water and energy use, as well as improved algal harvesting efficiencies (Ozkan et al. 2012; Berner et al. 2015). Biofilm systems also demonstrate greater $\mathrm{CO}_{2}$ utilization efficiency and reduced harvesting cost (Blanken 
et al. 2017; Roostaei et al. 2018). These systems, however, are also constrained, often relying on sophisticated artificial architectures to compete with the efficiency of natural systems and are much harder to scale up.

More recently, algae have also been cultivated while immobilized in hydrogels (Berner et al. 2015). Hydrogel immobilization enables reduced water usage during algal cultivation and provides a potential physical barrier against bacterial infections (Brenner et al. 2008; Covarrubias et al. 2012). 3D bioprinting has been used to create different hydrogel structures growing a range of microalgal strains (Krujatz et al. 2015; Lode et al. 2015; Wangpraseurt et al. 2020). To optimize light propagation in hydrogels with high microalgal densities, coral-inspired biomaterials have recently been developed (Wangpraseurt et al. 2020). However, the cultivation of microalgae in hydrogel-based systems still requires further development regarding the exchange of gases and metabolites that are essential for microalgal growth (Podola et al. 2017).

To overcome diffusion limitation in attached cultivation systems, previous efforts have included the development of porous substrate-based bioreactors that make use of a porous membrane to deliver nutrients and promote gas exchange, while the surface of the biofilm is in direct contact with the ambient gas phase (Podola et al. 2017). In nature, benthic photosynthetic symbiotic organisms (e.g., corals, anemones) have faced similar challenges as photosynthesis in thick tissues can theoretically become limited by the diffusion-limited provision of $\mathrm{HCO}_{3}{ }^{-}$from the ambient water phase (Schrameyer et al. 2014). However, it has been shown that coral animal and bacterial respiration promote photosynthesis of their symbiotic microalgae, suggesting that the coral host provides essential metabolites and nutrients locally to the microalgae (e.g., Kuhl et al. 1996; Schrameyer et al. 2014).

In corals, the microbial community performs critical functions for the coral holobiont including pathogen protection, sulfur, and nitrogen cycling as well as beneficial modulations of the host microhabitat (Rosenberg et al. 2009; Ceh et al. 2013; Krediet et al. 2013). Benefits of bacterial communities for an algal host have been documented in free-living algae as well (e.g., Kazamia et al. 2012). Some bacteria can provide a local supply of essential nutrient compounds required by the algae, including nitrogen, inorganic carbon, vitamin $\mathrm{B}_{12}$ (cobalamin), and growth-promoting hormones (Kouzuma and Watanabe 2015). For example, one study estimated that $50 \%$ of algal species are cobalamin auxotrophs, implying a reliance on bacterial-produced cobalamin (Croft et al. 2005). More generally, symbiotic relationships between microalgae and bacteria often employ a mutually beneficial exchange of carbon and nitrogen (Thompson et al. 2012; de-Bashan et al. 2016). Experiments working with the microalgae Chlorella in co-culture with a known growth-promoting bacteria in alginate beads demonstrated enhanced growth which can be utilized for biotechnological applications (Gonzalez and Bashan 2000). Likewise, Chlorella minutissima was co-cultured with Escherichia coli under mixotrophic conditions and resulted in enhanced production of biofuel precursors (Higgins and VanderGheynst 2014). Accordingly, there is a growing interest in exploiting the potential of algal-bacterial co-cultures for algal biotechnology (Lian et al. 2021; Sánchez-Zurano et al. 2020; Padmaperuma et al. 2018; Meyer and Nai 2018).

Here, we aimed to develop a simple gelatin-based hydrogel system by combining microalgae and bacteria for spaceefficient microalgal cultivation. We hypothesized that cocultivation of algae and bacteria would result in improved growth and performance of the algae in hydrogels. For this, we chose the green microalga Marinichlorella kaistiae KAS603 and screened 14 marine bacterial strains for beneficial effects on algal biomass. Based on these results, we further measured the bio-optical properties and photosynthetic performance of a synthetic co-culture between M. kaistiae KAS603 and a novel strain of Erythrobacter sp. We also aimed to evaluate the beneficial effects of the Erythrobacter strain on a range of microalgae covering coccolithophorids, red algae, and other species of green microalgae. Finally, the mechanical stability of our hydrogel system was tested under different environmental conditions.

\section{Methods}

\section{Experimental approach}

To test for beneficial effects of algal-bacterial co-culture, we assessed a range of bacterial and algal strains. Marinichlorella kaistiae KAS603 (Sánchez-Alvarez et al. 2017) was used as model algal strain. Marinichlorella kaistiae KAS603 is a robust algal strain that is morphologically similar to Chlorella and has high lipid and biomass production rates (Sánchez-Alvarez et al. 2017). Marinichlorella kaistiae KAS603 has been successfully grown in 3D bioprinted gelatin-based hydrogels (Wangpraseurt et al. 2020). The beneficial impact of 14 different bacterial strains isolated from Californian coastal waters (see Table S1) on M. kaistiae KAS603 growth was investigated over 3-day co-culture experiments in gelatinbased hydrogels (see cultivation methods and conditions below for details). These preliminary experiments suggested enhanced growth with the strain SIO_La6, closely related to Erythrobacter sp. (Table S1), which was then used as our bacterial model for co-culture experiments. Finally, to test whether these beneficial effects of SIO_La6 were transferrable across a diverse range of microalgal taxa (including diatoms, red algae, and coccolithophores), co-cultures between SIO_La6 and Micromonas sp., Porphyridium cruentum, Pleurochrysis carterae, and 
Amphidinium carterae were also investigated. Co-culture experiments with $M$. kaistiae KAS603 were conducted also in liquid culture to assess the relative effect of algae immobilization in hydrogels (Fig. S1).

\section{Stock cultures}

All bacterial strains were isolated from Californian coastal waters off Ellen Browning Scripps Memorial Pier and maintained in our bacterial culture collection at Scripps Institution of Oceanography. Bacterial stock cultures were cultivated in Zobell broth at $25^{\circ} \mathrm{C}$ under sterile conditions. Bacterial cultures used for hydrogel immobilization were harvested during exponential growth in Zobell broth as determined via optical density (OD) measurements (Begot et al. 1996) and flow cytometry (Gasol and Del Giorgio 2000). Bacterial cultures were identified by $16 \mathrm{~S}$ rDNA Sanger sequencing (using the primer pair 27F-1492R) to determine their closest phylogenetic relations (Table S1). Algal stock cultures were grown in artificial seawater medium (ASW, Darley and Volcani 1969) at $25{ }^{\circ} \mathrm{C}$ under a continuous irradiance regime of $150 \mu \mathrm{mol}$ photons $\mathrm{m}^{-2} \mathrm{~s}^{-1}$ provided by white LED light panels (AL-H36DS, Ray2; Finnex). Microalgae were harvested from liquid stock cultures in the exponential growth phase for hydrogel immobilization. Cell density was measured using a hemocytometer, with three technical replicate counts per algal stock sample.
Algal-bacterial hydrogel fabrication and cultivation

Hydrogels were made by using a $10 \%$ solution of porcine gelatin (type-A; Sigma-Aldrich, USA) in artificial seawater (ASW). The solution was prepared by heating the gelatin-ASW mixture on a hot plate under continuous stirring to $90^{\circ} \mathrm{C}$ until it was optically clear. The solution was cooled to $30^{\circ} \mathrm{C}$ and $2.5 \mathrm{~mL}$ of the gel solution was rapidly mixed with $2 \mathrm{~mL}$ of the algal stock solution (at a concentration of $1.36 \times 10^{7}$ cells $\mathrm{mL}^{-1}$ for main M. kaistiae experiments) and $0.5 \mathrm{~mL}$ of either sterile Zobell medium (for monoculture control gels) or Zobell medium containing a chosen bacterial strain (for co-culture gels) (Fig. 1). Bacterial density for cultivation experiments was chosen at an $\mathrm{OD}_{600}$ of 0.02 . We also performed preliminary growth experiments using different starting concentrations of microalgal cell density (Fig. S2). The solution was vortexed for $30 \mathrm{~s}$ to ensure proper mixing of algae and bacteria, before it was poured into Petri dishes. Gelation was facilitated by keeping the Petri dishes at $18{ }^{\circ} \mathrm{C}$ for $1 \mathrm{~h}$, which resulted in gels that were $\sim 10 \mathrm{~mm}$ thick. Gels were then cultivated at $25^{\circ} \mathrm{C}$ under a continuous irradiance regime of $150 \mu \mathrm{mol}$ photons $\mathrm{m}^{-2} \mathrm{~s}^{-1}$ provided by white LED light panels (AL-H36DS, Ray2; Finnex). For the main M. kaistiae growth experiments, 15 hydrogels were fabricated per treatment (monoculture or co-culture), yielding a total of 30 hydrogels of which 5 hydrogels were sampled on each of 3 experimental days. Additional co-cultivation experiments were performed to ensure reproducibility of the observed effects (see Supplementary information).

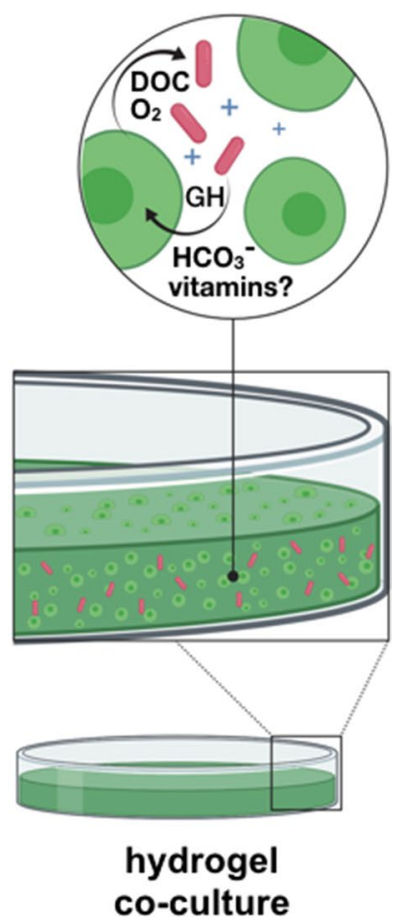

Fig. 1 Development of a synthetic co-culture between microalgae and Erythrobacter sp. in a gelatin-based hydrogel. Algae were grown in monoculture and in co-culture with Erythrobacter sp. both in liquid culture and in hydrogel configuration. Arrows indicate potential interactions between algae and bacteria that were hypothesized to enhance algal growth. Microalgal photosynthesis generates $\mathrm{O}_{2}$ and dissolved organic carbon (DOC) that fuels bacterial metabolism. In turn, bacterial activity provides an inorganic carbon source $\left(\mathrm{HCO}_{3}{ }^{-}\right)$for photosynthesis, vitamins, or growth hormones $(\mathrm{GH})$. This synthetic co-culture enhances the stability of the biopolymer when exposed to potential pathogens
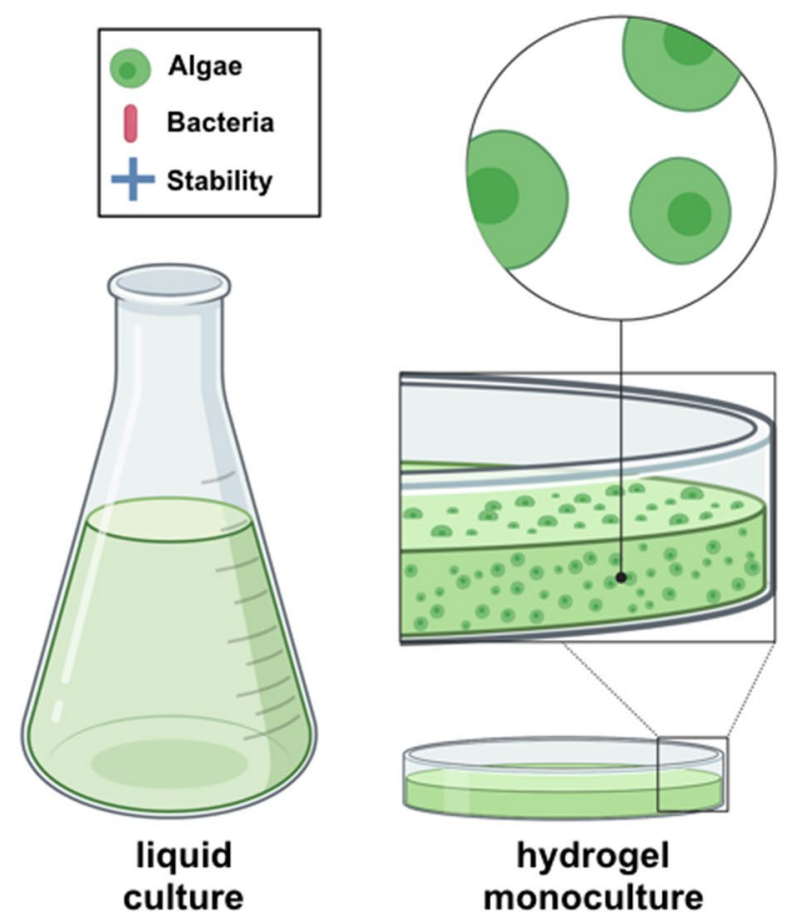

co-culture 


\section{Performance testing}

\section{Microalgal cell density}

Hydrogels were liquefied by heating to $30^{\circ} \mathrm{C}$ on a hot plate. The liquid algal suspension was then diluted with ASW and the cell density was determined with a hemocytometer (see above). The accuracy of this approach was tested using stock cultures of known cell density, showing an error of less than $3 \%$ between expected and measured cell densities.

\section{$\mathrm{O}_{2}$ microsensor measurements}

Clark-type $\mathrm{O}_{2}$ microsensors (tip size of $25 \mu \mathrm{m}$, a $90 \%$ response time of $<0.5 \mathrm{~s}$ and a stirring sensitivity of $\sim 1 \%$; Unisense $\mathrm{A} / \mathrm{S}$, Aarhus, Denmark) were used to measure net photosynthesis and dark respiration of the algal-bacterial hydrogels as described previously (Wangpraseurt et al. 2012). Briefly, microsensors were connected to a picoammeter (Unisense, Denmark) and operated by an automatic microsensor profiler (MU1; Pyroscience GmbH, Germany). Hydrogels were placed in a black acrylic flow chamber and flowing seawater was supplied at a flow velocity of $0.5 \mathrm{~cm} \mathrm{~s}^{-1}$ at $25{ }^{\circ} \mathrm{C}$ and a salinity of $35 \%$. Microsensors were positioned at the surface of the hydrogel by observing the microsensor tip with the aid of a dissecting microscope and the use of an automated micromanipulator (MU1; Pyroscience GmbH, Germany). Steady-state $\mathrm{O}_{2}$ concentration profiles from the hydrogel surface through the diffusive boundary layer (DBL) and into the mixed turbulent water phase above were performed in 100$\mu \mathrm{m}$ steps under an incident photon irradiance of $\mathrm{E}_{\mathrm{d}}(\mathrm{PAR})=0$ and $550 \mu \mathrm{mol}$ photons $\mathrm{m}^{-2} \mathrm{~s}^{-1}$. $\mathrm{O}_{2}$ microsensors were linearly calibrated from readings at $100 \%$ air saturated seawater at experimental temperature and using anoxic water (flushed with $\mathrm{N}_{2}$ ). Percent air saturation in seawater at experimental temperature and salinity was transformed to $\mathrm{O}_{2}$ concentration ( $\mu$ mol $\mathrm{O}_{2} \mathrm{~L}^{-1}$ ) using gas tables (Ramsing and Gundersen 2011).

\section{Variable chlorophyll a fluorimetry}

We used a variable chlorophyll $a$ fluorometer (diving PAM II, Walz, Germany) to characterize PS II performance (Baker 2008). The fiber of the PAM system was mounted on a laboratory stand and directed vertically toward the surface of the hydrogels at a fixed distance of $1 \mathrm{~cm}$. Hydrogels were dark adapted for at least $30 \mathrm{~min}$ before experimental measurements. Rapid light curves (RLC) (Ralph and Gademann 2005) were performed over a range of 8 irradiances spanning $0-1500 \mu \mathrm{mol}$ photons $\mathrm{m}^{-2} \mathrm{~s}^{-1}$ of incident downwelling irradiance. For each RLC, the dark-adapted hydrogels were incubated at each experimental irradiance regimes for $15 \mathrm{~s}$ followed by a saturation pulse.

\section{Bio-optical properties of the hydrogels}

Irradiance reflectance of the gels were measured with a 0.7-mm-wide flat-cut fiber-optic reflectance probe (Ocean Optics, USA) with the hydrogels positioned in the black acrylic flow-through system described above. The hydrogel was illuminated vertically incident by a light source emitting broadband white light. Reflectivity was determined with the reflectance probe positioned at a distance of $500 \mu \mathrm{m}$ from the hydrogel surface. All reflectivity measurements were normalized to the reflectivity of a 10,20 , and $99 \%$ white diffusing reflectance standard (Spectralon; Labsphere, USA). These measurements occurred under identical configuration and distance to light source as on the hydrogel surface but were performed in air. Measurements of scalar irradiance (i.e., the integral quantum flux from all directions around a given point) were measured with fiber-optic microsensors (zensor, Denmark) as described previously (Wangpraseurt et al. 2012).

\section{Bacterial contamination experiment}

To test whether the co-culture with Erythrobacter sp. SIO_ La6 strain would provide protection from other microbes, we exposed hydrogels $(n=8$ for each treatment for M. kaistiae KAS603 and $n=1$ per treatment for each Micromonas sp., $P$. cruentum, $P$. carterae, and $A$. carterae) to natural unsterilized seawater supplied from the Scripps Pier. For these tests, 3-day-old hydrogels were incubated with the natural seawater for $1.5 \mathrm{~h}$ in a beaker under low turbulent flow. The gels were then removed, and cultivation in the environmental growth room continued as described above. The gels were visually examined at every day after exposure and photographed to assess visual differences, such as noticeable cell death, bacterial growth, or hydrogel liquefaction, indicative of gelatin-degrading bacteria.

Data analysis The variable chlorophyll fluorescence data was analyzed as described previously (Ralph and Gademann 2005). Briefly, the maximum quantum yield of PSII was calculated as

$F_{v} / F_{m}=\left[F_{m}-F_{0}\right] / F_{m}$

and the effective quantum yield of PSII was calculated as

${ }_{P S I I}=\Delta F / F_{m^{\prime}}=\left[F_{m^{\prime}}-F\right] / F_{m}$

where $F_{0}$ and $F$ describe the minimum and transient fluorescence and $F_{m}{ }^{\prime}$ describes the maximum fluorescence in the light adapted state. The electron transport rate was calculated as $E T R=\Phi_{P S I I} \times E_{d} \times 0.5 \times A F$, where $E_{d}$ is the incident downwelling irradiance (400-700 nm), 0.5 assumes the equal distribution between PSI and PSII, and $A F$ denotes the 
absorption factor which was assumed to be 0.83 (Ralph and Gademann 2005). It is important to note that $A F$ will vary as a function of pigment and cell density and thus serves only as an approximation (Wangpraseurt et al. 2019). The photosynthetic light curves were fitted to the empirical equations of Platt and Gallegos (1980), using a Marquardt-Levenberg regression algorithm:

$P=P_{s}\left(1-\exp ^{-(\alpha E d / P s)}\right) \exp ^{-(\beta E d / P s)}$

where $P_{s}$ is a scaling factor defined as the maximum potential rETR, $\alpha$ describes the light use efficiency, i.e., the initial slope of the RLC and $\beta$ characterizes photoinhibition and indicates the slope of the RLC where PSII declines. The maximum electron transport rate $E T R_{\max }$ and the light intensity at half saturation $E_{k}$ were calculated as

$$
\begin{aligned}
& E T R_{\text {max }}=P S(\alpha /[\alpha+\beta])(\beta / \alpha+\beta)^{\beta / \alpha} \\
& E_{k}=E T R_{\max / \alpha}
\end{aligned}
$$

The fitting procedure was sensitive to initial guesses of PS, $\alpha$, and $\beta$, which were adjusted for each curve fitting. All fitting was done with custom codes written in Matlab (2018b).

Marinichlorella kaistiae KAS603 cell density, $\mathrm{F}_{\mathrm{v}} / \mathrm{F}_{\mathrm{m}}$, and $\mathrm{O}_{2}$ turnover were analyzed for significant differences $(\alpha<0.05)$ between co-culture and monoculture hydrogels using unpaired $t$ tests. All statistical results are provided in the supplementary information (Table S2).

\section{Results and discussion}

Here, we developed a simple hydrogel system for the spaceefficient co-culture of microalgae. We found that a novel strain of Erythrobacter sp. (SIO_La6, Fig. 2) isolated from Southern California coastal waters (off Scripps Pier) has beneficial effects on growth and photosynthetic performance of microalgae immobilized in hydrogels.

\section{Cell density differences between treatments}

Microalgal cell density was on average 2.3-fold enhanced for M. kaistiae KAS603 gels co-cultured with SIO_La6 $\left(\right.$ mean $=2.85 \times 10^{7}$ cells $\left.\mathrm{mL}^{-1}, \mathrm{SD}=5.94 \times 10^{6}, n=5\right)$ compared to monoculture gels $\left(1.18 \times 10^{7}\right.$ cells $\mathrm{mL}^{-1}$, $\mathrm{SD}=4.06 \times 10^{6}, n=5$ ) after $72 \mathrm{~h}$ of cultivation (unpaired $t$ test, $p<0.01$, Fig. 3a). The cell doubling time was $16.75 \mathrm{~h}$ for co-cultures compared to $33.11 \mathrm{~h}$ for monocultures (Fig. 3). The beneficial effects of co-culture with Erythrobacter sp. SIO_La6 were also evident in liquid culture, although the relative growth-stimulating effect was $15 \%$ higher in hydrogel cultivation (Supplementary Fig. 2). In a stagnant hydrogel, gas exchange is likely to become a limiting growth factor, while such limitation is unlikely to occur in a liquid mixed culture. Thus, the relative enhancement for hydrogel cultures
Fig. 2 Maximum likelihood tree of Alpha-proteobacteria sequences closely related to the tested isolates (SIO_La6). Reference sequences from NCBI are indicated in italic. Bootstrap values $(n=1000)$ are indicated at nodes; scale bar represents changes per position

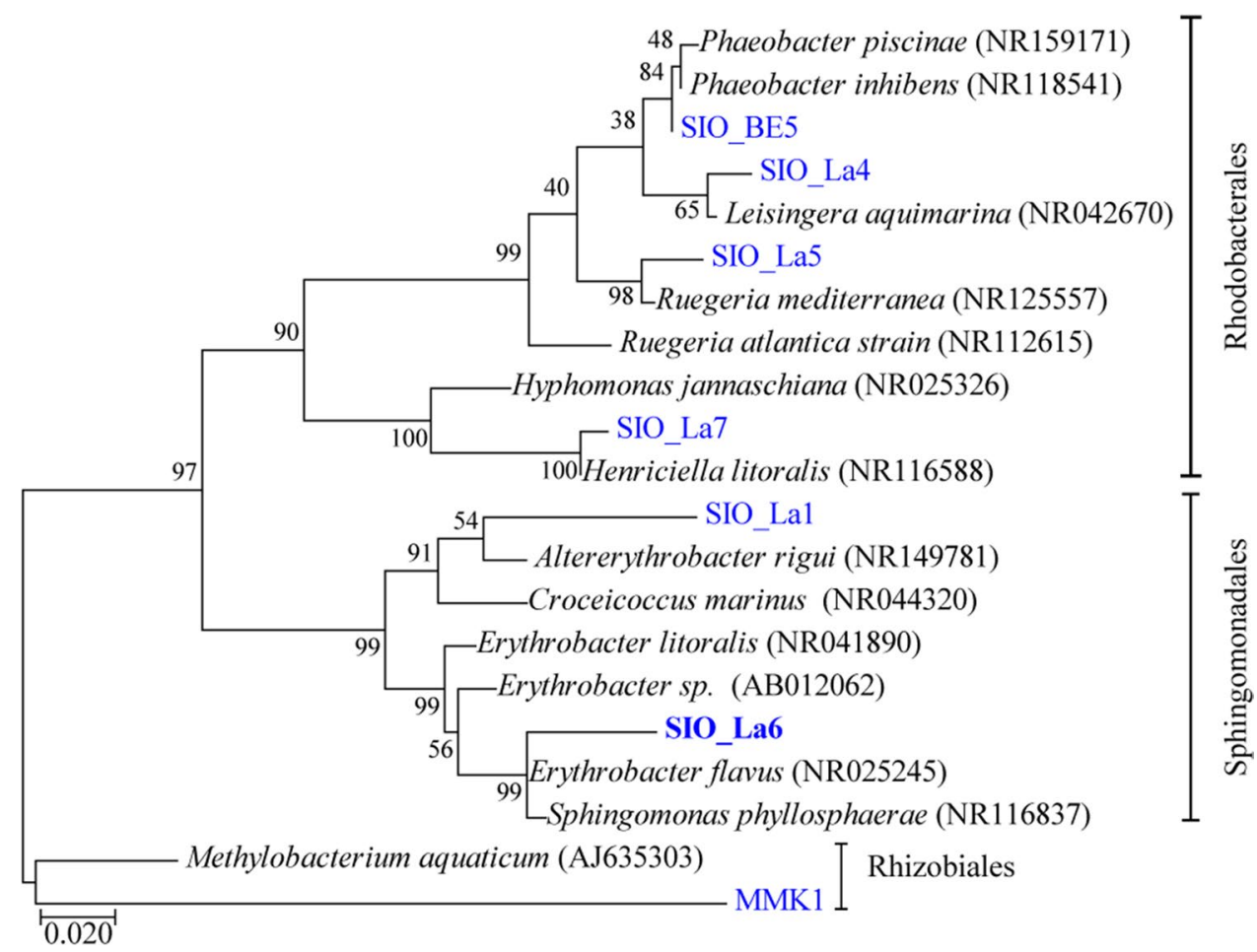




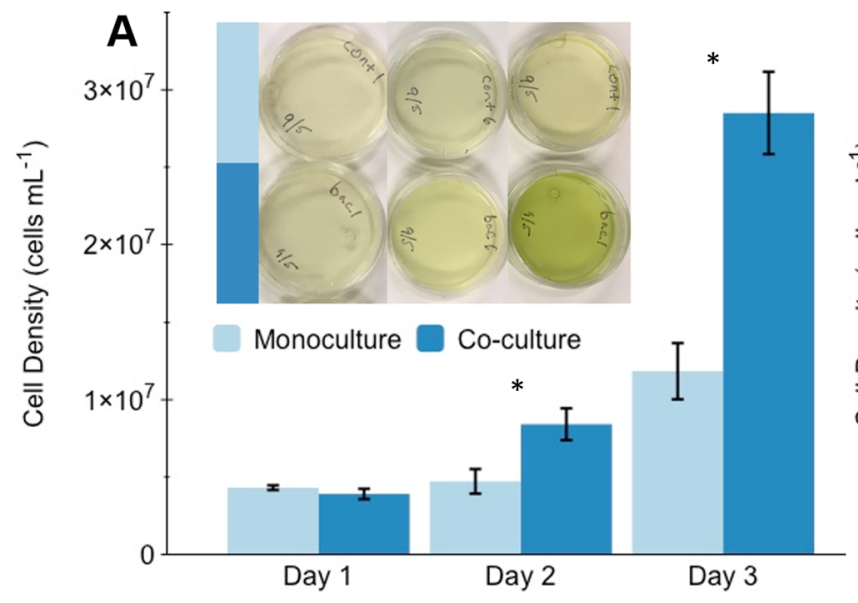

Fig. 3 Effect of algal-bacterial hydrogel co-culture on microalgal cell density growth. a 3-Day growth dynamics of Marinichlorella kaistiae KAS603 in monoculture (light blue) and in co-culture with Erythrobacter sp. SIO_La6 (dark blue). Insets show example top view images of hydrogels each day. Data are means $\pm \mathrm{SD}, n=5$. b

could suggest that bacterial colonies stimulate gas exchange and provide nutrients and/or growth-promoting hormones locally within the hydrogel. Indeed, bacteria observed during confocal microscopy were observed forming aggregates around algal cells (Supplementary Fig. 3). Likewise, it is known that different Erythrobacter strains induce aggregation of different diatom species (Tran et al. 2020). Previous research into immobilized algae-bacteria co-cultures have observed similar formations of aggregates and biofilms, which resulted in improved growth and stability (de-Bashan et al. 2011, 2016). This proximity, in a gel compared to liquid culture, may facilitate and/or stabilize the interactions between the algae and bacteria for provision of photosynthate from the algae and in return growth-enhancing micronutrients (e.g., vitamins) and gases (e.g., $\mathrm{CO}_{2}$ ) from bacteria (Kazamia et al. 2012; Paerl et al. 2015; Higgins et al. 2016; Helliwell 2017).

Following the successful tests with M. kaistiae KAS603, other common microalgae were tested in co-culture with SIO_La6. The bacterial co-culture enhanced microalgal growth for three of the five microalgal strains compared to monoculture controls (Fig. 3b). Cell densities after 3 days of cultivation were at least twofold higher for the coccolithophorid alga $P$. carterae and the red alga $P$. cruentum when grown in co-culture hydrogels (Fig. 3b). Interestingly, cultures that did not perform well in co-culture (e.g., Micromonas sp. and A. carterae) also showed limited growth when encapsulated in the gelatin-based hydrogel in monoculture, suggesting that hydrogel immobilization interfered with the growth dynamics of these algae (Fig. 3b). This suggests that Micromonas sp. and A. carterae might not be suitable candidates for biotechnological applications using hydrogel immobilization. Understanding the metabolic

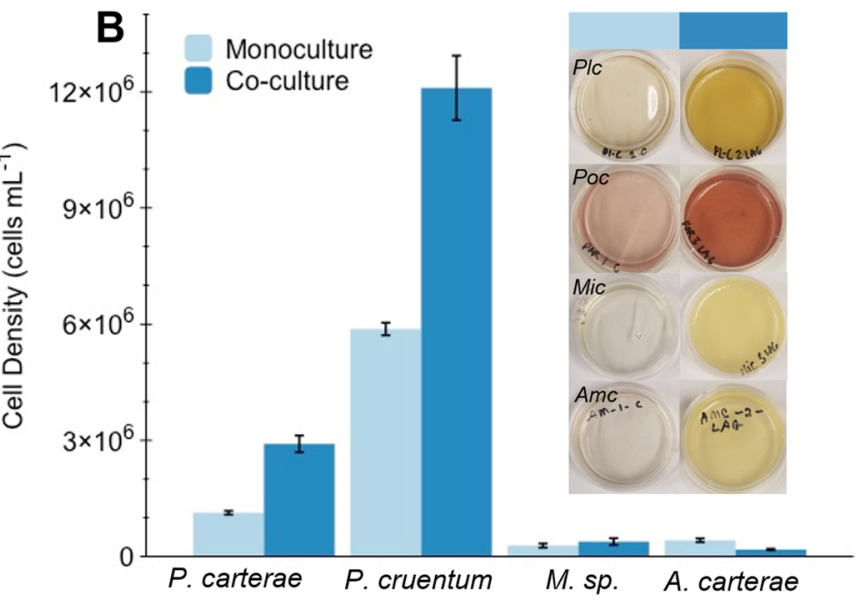

Cell density of Pleurochrysis carterae, Porphyridium cruentum, Micromonas sp., and Amphidinium carterae after 8 days of growth in monoculture and co-culture. Images show top view images of hydrogel after 8 days. Data are means $\pm \mathrm{SD} n=2$. * indicates a significant difference between treatments ( $p<0.05$, unpaired Student's $t$ test)

and molecular mechanisms underlying this beneficial interaction is a complex task that would require potential metabolomic and proteomic approaches (see, e.g., Kazamia et al. 2016; Helliwell et al. 2018) which was beyond the scope of the present study. However, it is noteworthy that we found growth-enhancing effects of Erythrobacter SIO_LA6 on vitamin $\mathrm{B}_{12}$-independent algae (M. kaistiae KAS603) and vitamin $\mathrm{B}_{12}$-dependent algae (P. carterae, Croft et al. 2005). This suggests that the beneficial effects are unlikely due to vitamin production by Erythrobacter SIO_LA6 and rather related to other benefits (e.g., growth hormones or gas exchange).

\section{Co-culture effects on microalgal photosynthesis and bio-optics}

Compared to M. kaistiae KAS603 monocultures, $\mathrm{O}_{2}$ microsensor measurements in co-cultures indicated 4.9fold enhancements of net photosynthesis at high light (550 $\mu \mathrm{mol}$ photons $\mathrm{m}^{-2} \mathrm{~s}^{-1}$ ) irradiance regimes (Fig. 4a). In addition, co-cultures exhibited about 4.3-fold greater rates of dark respiration (Fig. 4a). Variable chlorophyll- $a$ fluorimetry measurements showed significant enhancements in the maximum quantum yield of PSII $\left(\mathrm{F}_{\mathrm{v}} / \mathrm{F}_{\mathrm{m}}\right)$ for co-culture hydrogels compared to monoculture hydrogels during 7 days of growth (mean $=0.603, S D=0.022$ vs. mean $=0.535, \mathrm{SD}=0.004$, respectively; Fig. $4 \mathrm{~b}$, unpaired $t$ test $p=0.0339) . \mathrm{F}_{\mathrm{v}} / \mathrm{F}_{\mathrm{m}}$ is a key parameter used to assess the healthiness of photosynthesizing microalgae (e.g., Baker 2008) and thus suggests that algae in co-culture displayed superior photosynthetic capacities. Likewise, relative electron transport rates showed clear differences 
Fig. 4 Photosynthetic performance of hydrogels in monoand co-culture. a $\mathrm{O}_{2}$ turnover $\left(\mathrm{nmol} \mathrm{O} \mathrm{cm}^{-2} \mathrm{~s}^{-1}\right.$ ) based on $\mathrm{O}_{2}$ microsensor measurements of the linear $\mathrm{O}_{2}$ flux from the surface into the diffusive boundary layer performed at 0 (dark respiration) and at $550 \mu \mathrm{mol}$ photons $\mathrm{m}^{-2} \mathrm{~s}^{-1}$ (net photosynthesis). b Maximum quantum yield of PSII $\left(\mathrm{F}_{\mathrm{v}} / \mathrm{F}_{\mathrm{m}}\right)$ and electron transport rates (ETR) at $\mathbf{c}$ day $2, \mathbf{d}$ day 3 , and $\mathbf{e}$ day 7 of algal cultivation. Data are means \pm SD $(n=4$ for panel a and $n=3$ for panels $\mathbf{b}-\mathbf{e})$. Note that $y$-axis scale was adjusted for clarity in panels c-e. * indicates a significant difference between treatments $(p<0.05$, unpaired Student's $t$ test)
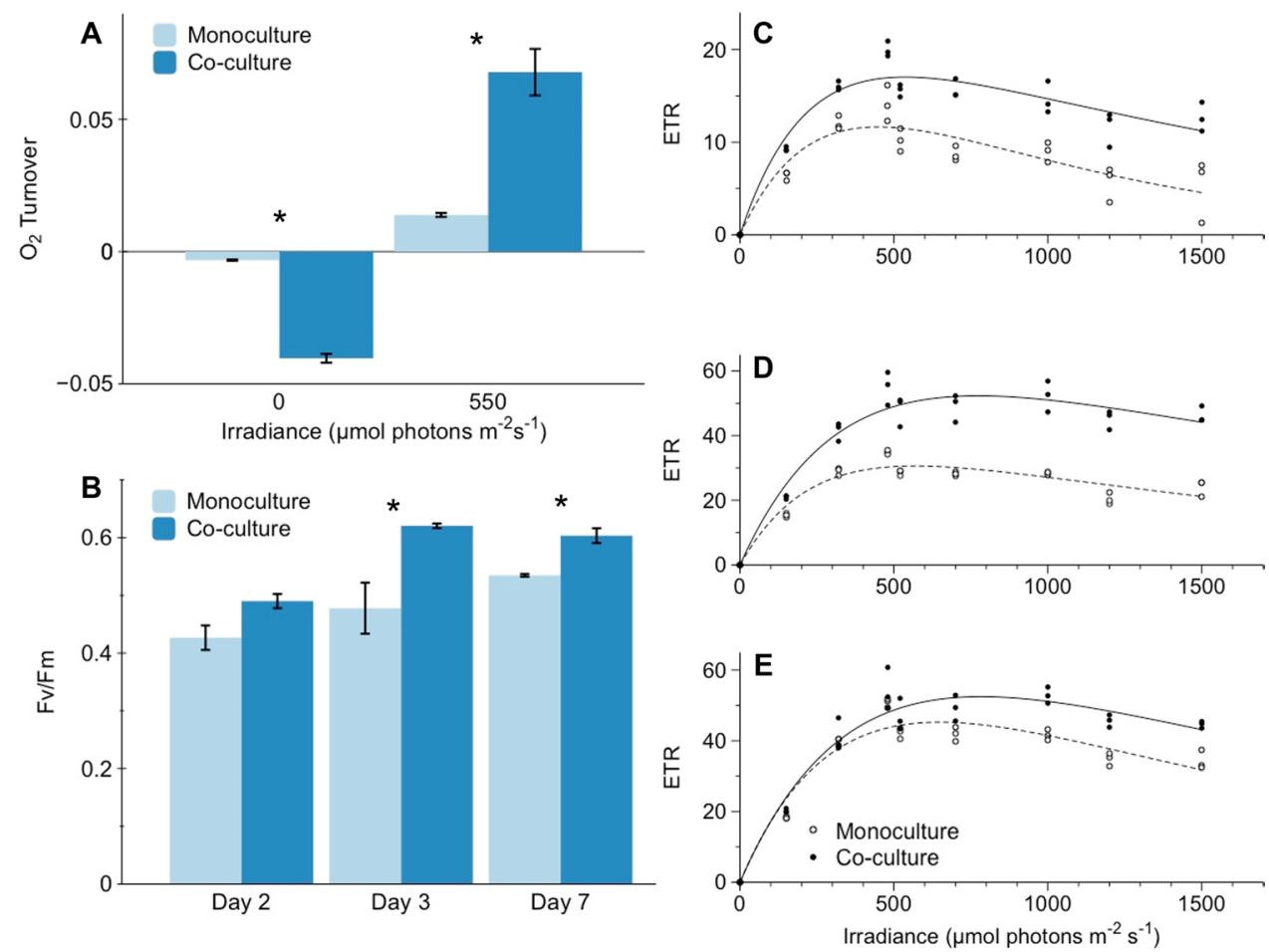

in key photosynthetic parameters including $\alpha$ and $\mathrm{ETR}_{\text {max }}$ (Fig. 4d-f, Table 1). For instance, at day 3 ETR $_{\max }$ was about $71.6 \%$ higher for cocultures versus monocultures (Fig. 4d-f, Table 1).

Although areal net photosynthetic $\left(P_{\mathrm{n}}\right)$ rates were strongly enhanced in co-culture, these differences were also affected by the greater algal growth in co-culture (Fig. 3). However, normalizing $P_{\mathrm{n}}$ rates to the differences in biomass still suggests an approximate doubling in net photosynthesis in co-culture versus monoculture (compare Figs. 3a and 4a). As Erythrobacter spp. are anoxygenic phototrophic bacteria and thus does not produce $\mathrm{O}_{2}$ (Koblizek et al. 2003), such differences strongly suggest cell-specific enhancements of photosynthetic activity by M. kaistiae KAS603 in the presence of Erythrobacter. It is important to note that these measurements include respiratory activity by the bacteria, further strengthening the argument of enhanced algal photosynthesis in co-culture. PAM measurements can detect potential electron transport by Eyrythrobacter sp. (Chandaravithoon et al. 2020); however, we did not find any measurable quantum yield of PSII from SIO_LA6 in monoculture $\left(\mathrm{F}_{\mathrm{v}} /\right.$ $\mathrm{F}_{\mathrm{m}}=0$, data not shown). In addition, diffuse reflectance measurements did not show characteristic absorption peaks of bacteriochlorophyll $a$ at $~ 750 \mathrm{~nm}$ (Fig. 5, Yurkov and Beatty 1998), suggesting that pigment synthesis and photosynthetic electron transport might be low by this Erythrobacter strain. In turn, reflectance in the nearinfrared region $(\sim 750 \mathrm{~nm})$ was about 2.5 -fold enhanced which could be indicative of the production of lightscattering microbial extracellular polymeric substances (EPS; Flemming and Wingender 2001). Such EPS has previously been shown to scatter light and could potentially enhance the internal actinic irradiance intensity which would further promote photosynthesis (Decho et al. 2003; Fisher et al. 2019). Clearly, there are various potential
Table 1 Photosynthetic performance of Marinichlorella kaistiae KAS603 grown in the hydrogel alone (monoculture) or together with Erythrobacter sp. SIO_La6 (co-culture)

\begin{tabular}{|c|c|c|c|c|c|c|}
\hline & \multicolumn{2}{|l|}{ Day 2} & \multicolumn{2}{|l|}{ Day3 } & \multicolumn{2}{|l|}{ Day7 } \\
\hline & Monoculture & Co-culture & Monoculture & Co-culture & Monoculture & Co-culture \\
\hline$\alpha$ & 0.07 & 0.10 & 0.17 & 0.21 & 0.21 & 0.20 \\
\hline$\beta$ & 0.04 & 0.015 & 0.03 & 0.034 & 0.06 & 0.05 \\
\hline $\mathrm{ETR}_{\max }$ & 11.64 & 17.03 & 30.59 & 52.30 & 45.26 & 52.5 \\
\hline$E_{k}$ & 158 & 169 & 180 & 245 & 220 & 261 \\
\hline$R^{2}$ & 0.8 & 0.90 & 0.91 & 0.93 & 0.93 & 0.94 \\
\hline
\end{tabular}

Parameters are derived from the best fit from all replicate measurements $(n=3$, lines in Fig. 4c-e) 
Fig. 5 Hydrogel diffuse reflectance (\%) after a day 1 , b day 2 , and $\mathbf{c}$ day 3 of algal cultivation. Data are means from 3 hydrogels, error bars are omitted for clarity (SD was less than 5\%)

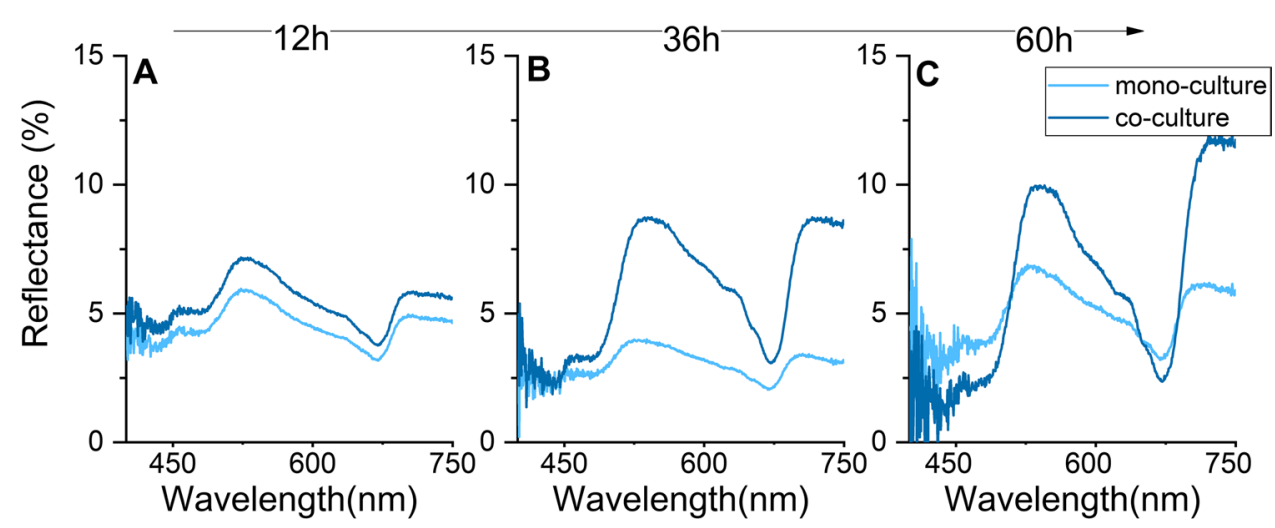

mechanisms underlying the enhanced photosynthetic performance of the co-culture hydrogels and a detailed understanding of the mechanisms was beyond the scope of this first study. However, taken together, our results indicate that Erythrobacter sp. SIO_La6 enhances $M$. kaistiae KAS603 photosynthesis (Table 1) which could explain the enhanced algal biomass in co-culture.

\section{Contamination resistance in hydrogels}

A potential key problem in cultivating microalgae in hydrogels is that most biopolymers are readily degraded by various bacterial communities (Pathak et al. 2017). We hypothesized that co-cultivation might provide protection from such degradation by occupying microbial habitats within the hydrogel and potentially producing antibiotics. Such concept is analogous to the role of the microbial community in the coral mucus, which protects from opportunistic microbes (Shnit-Orland and Kushmaro 2009). Following exposure to natural seawater, co-culture gels remained viable and no visible degradation of the gelatin matrix was noticeable even after 7 days of cultivation (Fig. 6a-e). However, monocultures showed clear degradation and liquefaction of the polymer matrix within $24 \mathrm{~h}$ (Fig. 6a-e). Likewise, previous experiments using Chlorella-bacteria co-cultures in alginate beads found reduced contamination by foreign bacteria from the environment and concluded that co-cultured bacteria provide a physical barrier (Covarrubias et al. 2012). Here, it is likely that DOC produced by the algae might enhance virulence factors (present in SIO_La6 genomes, J. Dinasquet personal communication) and toxin production as observed in other Erythrobacter species in the presence of algal DOC (Cárdenas et al. 2018). This induced pathogenicity might have antagonistic effects against environmental contaminants. Although the mechanisms warrant further investigation, these initial results suggest protective effects of our synthetic co-culture hydrogel from external microbes. Thus, co-cultivation with Erythrobacter SIO_LA6 stabilizes the biopolymer matrix and reduces the chance for bacterial degradation. This could therefore reduce the need for costly measures to prevent invasion by adventitious bacteria or other predators that might be attracted by the breakdown products. Given that surfaceassociated/biofilm-based cultivation methods are increasing in various algal biotechnological applications, our study

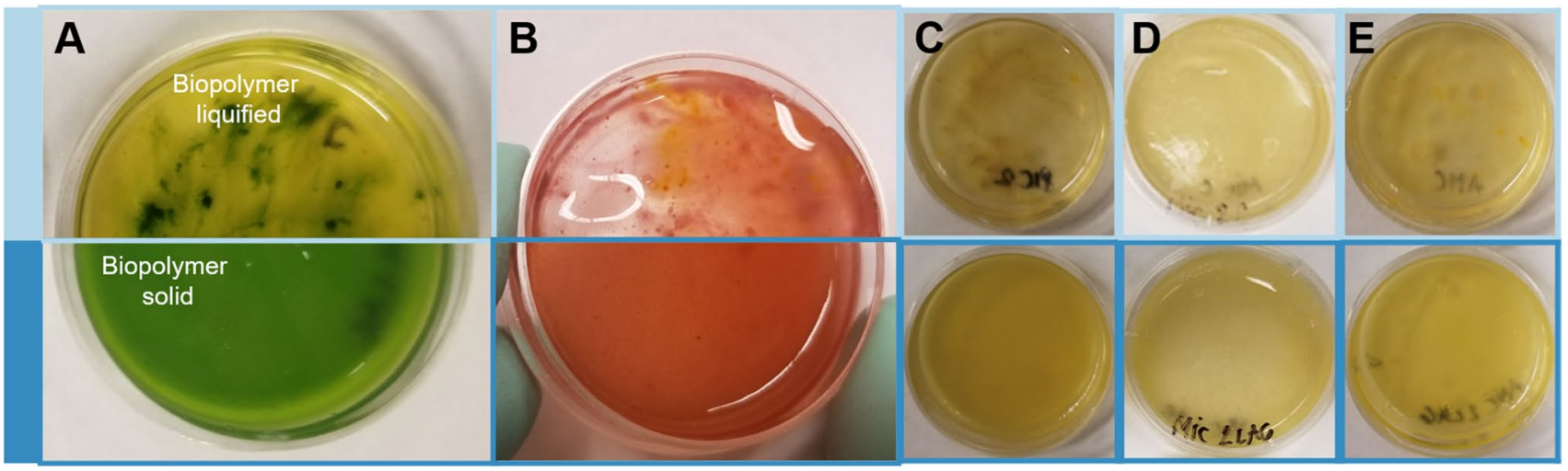

Fig. 6 Biopolymer stability after exposure to natural seawater. Images show top view of hydrogels after 7 days of the seawater exposure experiment. Monocultures (top panels, light blue) are liquefied while co-cultures remain solid (bottom panels, dark blue) for a Marinichlorella kaistiae KAS603, b Porphyridium cruentum, c Pleurochrysis carterae, d Micromonas sp., and e Amphidinium carterae 
potentially provides a simple and cheap cultivation system with minimal maintenance requirements. This approach can be further developed as a viable bio-inspired alternative to costly antibiotic treatments that are currently used in such cultivation approaches (Berner et al. 2015).

\section{Conclusions}

This study developed a simple hydrogel system for microalgal cultivation in co-culture with a novel strain of Erythrobacter $\mathrm{sp}$. Our findings demonstrate enhanced photosynthetic activity and growth rates of microalgae in co-culture when immobilized in our hydrogel system. We further show that our gelatin-based hydrogel is easy to fabricate, requires low maintenance, and remains stable when the co-culture is exposed to natural contaminants. Our study suggests that co-cultivation in hydrogels of microalgae with Erythrobacter sp. enhances microalgal growth and density, and could potentially reduce the need for costly antibiotics. We conclude that hydrogel algal-bacterial co-culture is a simple, bio-inspired approach that can be further developed to solve some problems that currently limit microalgal cultivation. These improvements compared to conventional cultivation methods demonstrate potential practical applications of our findings toward more efficient micro-algal cultivation.

Supplementary Information The online version contains supplementary material available at https://doi.org/10.1007/s10811-021-02528-7.

Acknowledgements Mark Hildebrand is thanked for initial input on the experimental approach and for providing Marinchlorella cultures. Orna Cook is thanked for providing algal cultures. Mike Allen is thanked for excellent technical assistance.

Author contribution Conceptualized and designed the study: D.W., J.D., N.M., T.B., S.V., A.G.S., M.D. Performed experimental measurements: N.M., T.B., A.S., A.D. Analyzed and interpreted data: N.M., T.B. D.W. Provided reagents, materials, and analysis tools: D.W., J.D., D.D.D., S.V., F.A., J.E.S. Supervised the study: D.W., S.V., D.D.D. Wrote the manuscript: N.M., T.B., D.W. All authors critically assessed the results and edited drafts of the manuscript.

Funding This study was funded by the European Union's Horizon 2020 research and innovation programme (702911-BioMIC-FUEL, D.W., D.D.D., S.V.), the European Research Council (ERC-2020-COG-GA BiTe 101001637), the European Union's 7th Framework programme (PIOF-GA-2013-629378, J.D.), and the Gordon and Betty Moore Foundation (Grant GBMF4827, F.A.).

Data availability All raw data generated during this study are deposited on figshare (https://doi.org/10.6084/m9.figshare.14691246).

Open Access This article is licensed under a Creative Commons Attribution 4.0 International License, which permits use, sharing, adaptation, distribution and reproduction in any medium or format, as long as you give appropriate credit to the original author(s) and the source, provide a link to the Creative Commons licence, and indicate if changes were made. The images or other third party material in this article are included in the article's Creative Commons licence, unless indicated otherwise in a credit line to the material. If material is not included in the article's Creative Commons licence and your intended use is not permitted by statutory regulation or exceeds the permitted use, you will need to obtain permission directly from the copyright holder. To view a copy of this licence, visit http://creativecommons.org/licenses/by/4.0/.

\section{References}

Baker NR (2008) Chlorophyll fluorescence: a probe of photosynthesis in vivo. Annu Rev Plant Biol 59:89-113

Begot C, Desnier I, Daudin JD, Labadie JC, Lebert A (1996) Recommendations for calculating growth parameters by optical density measurements. J Microbiol Method 25:225-232

Berner F, Heimann K, Sheehan M (2015) Microalgal biofilms for biomass production. J Appl Phycol 27:1793-1804

Blanken W, Schaap S, Theobald S, Rinzema A, Wijffels RH, Janssen M (2017) Optimizing carbon dioxide utilization for microalgae biofilm cultivation. Biotechnol Bioeng 114:769-776

Borowitzka MA (2013) High-value products from microalgae-their development and commercialisation. J Appl Phycol 25:743-756

Borowitzka MA, Vonshak A (2017) Scaling up microalgal cultures to commercial scale. Eur J Phycol 52:407-418

Brenner K, You L, Arnold FH (2008) Engineering microbial consortia: a new frontier in synthetic biology. Trends Biotechnol 26:483-489

Cárdenas A, Neave MJ, Haroon MF, Pogoreutz C, Rädecker N, Wild C, Gärdes A, Voolstra CR (2018) Excess labile carbon promotes the expression of virulence factors in coral reef bacterioplankton. ISME J 12:59-76

Ceh J, Kilburn MR, Cliff JB, Raina J-B, van Keulen M, Bourne DG (2013) Nutrient cycling in early coral life stages: Pocillopora damicornis larvae provide their algal symbiont (Symbiodinium) with nitrogen acquired from bacterial associates. Ecol Evol 3:2393-2400

Chandaravithoon P, Ritchie RJ, Runcie JW (2020) Measuring photosynthesis of both oxygenic and anoxygenic photosynthetic organisms using pulse amplitude modulation (PAM) fluorometry in wastewater ponds. J Appl Phycol 32:2615-2629

Covarrubias SA, De-Bashan LE, Moreno M, Bashan Y (2012) Alginate beads provide a beneficial physical barrier against native microorganisms in wastewater treated with immobilized bacteria and microalgae. Appl Microbiol Biotechnol 93:2669-2680

Croft MT, Lawrence AD, Raux-Deery E, Warren MJ, Smith AG (2005) Algae acquire vitamin $B_{12}$ through a symbiotic relationship with bacteria. Nature 438:90-93

Darley WM, Volcani BE (1969) Role of silicon in diatom metabolism. A silicon requirement for deoxyribonucleic acid synthesis in the diatom Cylindrotheca fusiformis Reimann and Lewin. Exp Cell Res 58:334-342

de-Bashan LE, Mayali X, Bebout BM, WeberPK, Detweiler AM, HernandezJ-P, Prufert-BeboutL, Bashan Y (2016) Establishment of stable synthetic mutualism without co-evolution between microalgae and bacteria demonstrated by mutual transfer of metabolites (NanoSIMS isotopic imaging) and persistent physical association (fluorescent in situ hybridization). Algal Res 15:179-186

de-Bashan LE, Schmid M, Rothballer M, Hartmann A, Bashan Y (2011) Cell-cell interaction in the eukaryote-prokaryote model of the microalgae Chlorella vulgaris and the bacterium Azospirillum brasilense immobilized in polymer beads. J Phycol 47:1350-1359

Decho AW, Kawaguchi T, Allison MA, Louchard EM, Reid RP, Stephens FC, Voss KJ, Wheatcroft RA, Taylor BB (2003) Sediment 
properties influencing upwelling spectral reflectance signatures: The "biofilm gel effect." Limnol Oceanogr 48:431-443

Fisher A, Wangpraseurt D, Larkum AWD, Johnson M, Kühl M, Chen M, Wong HL, Burns BP (2019) Correlation of bio-optical properties with photosynthetic pigment and microorganism distribution in microbial mats from Hamelin Pool, Australia. FEMS Microbiol Ecol 95(1):fiy219. https://doi.org/10.1093/femsec/fiy219

Flemming HC, Wingender J (2001) Relevance of microbial extracellular polymeric substances (EPSs) - Part I: structural and ecological aspects. Water Sci Technol 43:1-8

Gasol JM, del Giorgio PA (2000) Using flow cytometry for counting natural planktonic bacteria and understanding the structure of planktonic bacterial communities. Sci Mar 2:197-224

Gonzalez LE, Bashan Y (2000) Increased growth of the microalga Chlorella vulgaris when coimmobilized and cocultured in alginate beads with the plant-growth-promoting bacterium Azospirillum brasilense. Appl Environ Microbiol 66:1527-1531

Helliwell KE (2017) The roles of B vitamins in phytoplankton nutrition: new perspectives and prospects. New Phytol 216:62-68

Helliwell KE, Pandhal J, Cooper MB, Longworth J, Kudahl UJ, Russo DA, Tomsett EV, Bunbury F, Salmon DL, Smirnoff N, Wright PC, Smith AG (2018) Quantitative proteomics of a $B_{12}$-dependent alga grown in coculture with bacteria reveals metabolic tradeoffs required for mutualism. New Phytol 217:599-612

Higgins BT, Gennity I, Samra S, Kind T, Fiehn O, VanderGheynst JS, (2016) Cofactor symbiosis for enhanced algal growth, biofuel production, and wastewater treatment. Algal Res 17:308-315

Higgins BT, VanderGheynst JS (2014) Effects of Escherichia coli on mixotrophic growth of Chlorella minutissima and production of biofuel. PLoS One 9:e96807

Kazamia E, Czesnick H, Nguyen TT, Croft MT, Sherwood E, Sasso S, Hodson SJ, Warren MJ, Smith AG (2012) Mutualistic interactions between vitamin $\mathrm{B}_{12}$-dependent algae and heterotrophic bacteria exhibit regulation. Environ Microbiol 14:1466-1476

Kazamia E, Helliwell KE, Purton S, Smith AG (2016) How mutualisms arise in phytoplankton communities: building eco-evolutionary principles for aquatic microbes. Ecol Lett 19:810-822

Khan MI, Shin JH, Kim JD (2018) The promising future of microalgae: current status, challenges, and optimization of a sustainable and renewable industry for biofuels, feed, and other products. Microb Cell Fact 17:1-21

Koblízek M, Béjà O, Bidigare RR, Christensen S, Benitez-Nelson B, Vetriani C, Kolber MK, Falkowski PG, Kolber ZS (2003) Isolation and characterization of Erythrobacter sp. strains from the upper ocean. Arch Microbiol 180:327-338

Kouzuma A, Watanabe K (2015) Exploring the potential of algae/bacteria interactions. Curr Opin Biotechnol 33:125-129

Krediet CJ, Ritchie KB, Paul VJ, Teplitski M (2013) Coral-associated micro-organisms and their roles in promoting coral health and thwarting diseases. Proc R Soc B 280:20122328

Krujatz F, Lode A, Brüggemeier S, Schütz K, Kramer J, Bley T, Gelinsky M, Wever J (2015) Green bioprinting: viability and growth analysis of microalgae immobilized in 3D-plotted hydrogels versus suspension cultures. Eng Life Sci 15:678-688

Kühl M, Glud RN, Ploug H, Ramsing NB (1996) Microenvironmental control of photosynthesis and photosynthesis-coupled respiration in an epilithic cyanobacterial biofilm. J Phycol 32:799-812

Lee YK (2001) Microalgal mass culture systems and methods: their limitation and potential. J Appl Phycol 13:307-315

Lian J, Schimmel P, Sanchez-Garcia S, Wijffels RH, Smidt H, Sipkema D (2021) Different co-occurring bacteria enhance or decrease the growth of the microalga Nannochloropsis sp. CCAP211/78. Microb Biotechnol 14:1159-1170

Lode A, Krujatz F, Brüggemeier S, Quade M, Schütz K, Knaack S, Weber J, Bley T, Gelinsky M (2015) Green bioprinting: fabrication of photosynthetic algae-laden hydrogel scaffolds for biotechnological and medical applications. Eng Life Sci $15: 177-183$

Meyer V, Nai C (2018) From axenic to mixed cultures: technological advances accelerating a paradigm shift in microbiology. Trends Microbiol 26:538-554

Ozkan A, Kinney K, Katz L, Berberoglu H (2012) Reduction of water and energy requirement of algae cultivation using an algae biofilm photobioreactor. Bioresour Technol 114:542-548

Padmaperuma G, Kapoore RV, Gilmour DJ, Vaidyanathan S (2018) Microbial consortia: a critical look at microalgae co-cultures for enhanced biomanufacturing. Crit Rev Biotechnol 38:690-703

Paerl RW, Bertrand EM, Allen AE, Palenik B, Azam F (2015) Vitamin B1 ecophysiology of marine picoeukaryotic algae: strain-specific differences and a new role for bacteria in vitamin cycling. Limnol Oceanogr 60:215-228

Pathak M, Sarma HK, Bhattacharyya KG, Subudhi S, Bisht V, Lal B, Devi A et al (2017) Characterization of a novel polymeric bioflocculant produced from bacterial utilization of $n$-hexadecane and its application in removal of heavy metals. Front Microbiol 8:170

Platt T, Gallegos CL (1980) Modelling primary production. In: Falkowski PG (ed) Primary productivity in the sea. Plenum Press, NY, pp 339-362

Podola B, Li T, Melkonian M (2017) Porous substrate bioreactors: a paradigm shift in microalgal biotechnology? Trends Biotechnol $35: 121-132$

Posten C (2009) Design principles of photo-bioreactors for cultivation of microalgae. Eng Life Sci 9:165-177

Ralph PJ, Gademann R (2005) Rapid light curves: a powerful tool to assess photosynthetic activity. Aquat Bot 82:222-237

Ramsing N, Gundersen J (2011) Seawater and gases. Limnol Oceanogr 37:1307-1312

Roostaei J, Zhang Y, Gopalakrishnan K, Ochocki AJ (2018) Mixotrophic microalgae biofilm: a novel algae cultivation strategy for improved productivity and cost-efficiency of biofuel feedstock production. Sci Rep 8:12528

Rosenberg E, Kushmaro A, Kramarsky-Winter E, Banin E, Yossi L (2009) The role of microorganisms in coral bleaching. ISME J 3:139-146

Sánchez-Alvarez EL, González-Ledezma G, Bolaños Prats JA et al (2017) Evaluating Marinichlorella kaistiae KAS603 cell size variation, growth and TAG accumulation resulting from rapid adaptation to highly diverse trophic and salinity cultivation regimes. Algal Res 25:12-24

Sánchez-Zurano A, Serrano CG, Acíen-Fernández FG, FernándezSevilla JM, Molina-Grima E (2020) Modeling of photosynthesis and respiration rate for microalgae-bacteria consortia. Biotechnol Bioeng 118:952-962

Schrameyer V, Wangpraseurt D, Hill R, Kühl M, Larkum AWD, Ralph PJ (2014) Light respiratory processes and gross photosynthesis in two scleractinian corals. PLoS ONE 9:e110814

Shnit-Orland M, Kushmaro A (2009) Coral mucus-associated bacteria: a possible first line of defense. FEMS Microbiol Ecol 67:371-380

Subashchandrabose SR, Ramakrishnan B, Megharaj M, Venkateswarlu K, Naidu R (2011) Consortia of cyanobacteria/microalgae and bacteria: biotechnological potential. Biotechnol Adv 29:896-907

Tan JS, Lee SY, Chew KW, Lam MK, Lim JW, Ho SH, Show PL (2020) A review on microalgae cultivation and harvesting, and their biomass extraction processing using ionic liquids. Bioengineering 11:116-129

Thompson AW, Foster RA, Krupke A, Carter BJ, Musat N, Vaulot D, Kuypers MMM, Zehr JP (2012) Unicellular cyanobacterium symbiotic with a single-celled eukaryotic alga. Science 337:1546-1550

Tran NA, Tamburic B, Evenhuis CR, Seymour JR (2020) Bacteriamediated aggregation of the marine phytoplankton Thalassiosira 
weissflogii and Nannochloropsis oceanica. J Appl Phycol 32:3735-3748

Villarruel-López A, Ascencio F, Nuño K (2017) Microalgae, a potential natural functional food source-a review. Pol J Food Nutr Sci 67:251-264

Wang H, Hill RT, Zheng T, Hu X, Wang B (2016) Effects of bacterial communities on biofuel-producing microalgae: stimulation, inhibition and harvesting. Crit Rev Biotechnol 36:341-352

Wangpraseurt D, Larkum AW, Ralph PJ, \& Kühl M (2012) Light gradients and optical microniches in coral tissues. Front Microbiol 3:316. https://doi.org/10.3389/fmicb.2012.0031

Wangpraseurt D, Lichtenberg M, Jacques SL, Larkum AW, Kühl M (2019) Optical properties of corals distort variable chlorophyll fluorescence measurements. Plant Physiol 179:1608-1619
Wangpraseurt D, You S, Azam F, Jacucci G, Gaidarenko O, Hildebrand M, Kühl M, Smith AG, Davey MP, Smith A, Deheyn DD, Chen S, Vignolini S (2020) Bionic 3D printed corals. Nat Commun 11:1748

Wyatt PJ (1969) Identification of bacteria by differential light scattering. Nature 221:1257-1258

Yurkov VV, Beatty JT (1998) Aerobic anoxygenic phototrophic bacteria. Microbiol Mol Biol Rev 62:695-724

Publisher's Note Springer Nature remains neutral with regard to jurisdictional claims in published maps and institutional affiliations. 